\title{
The impact of dapagliflozin on cardiovascular system in the course of type 2 diabetes mellitus
}

\begin{abstract}
The following paper is an attempt to revise current data and the results of clinical trials concerning the impact of dapagliflozin on long-term cardiovascular complications of type 2 diabetes mellitus. Short-term clinical trials, including relatively small groups of patients, suggest positive influence of dapagliflozin on the cardiovascular system. Currently ongoing long-term trials are likely to confirm these data, but so far we can assume that dapagliflozin not only acts as an efficient antihyperglycaemic drug, but also protects the circulatory system in patients with type 2 diabetes mellitus. (Clin Diabetol 2017; 6, 4: 142-146)
\end{abstract}

Key words: dapagliflozin, risk factors, cardiovascular events, atherosclerosis

\section{Introduction}

Cardiovascular complications of diabetes are one of the basic, still unresolved issues in the treatment of
Address for correspondence:

mgr farm. Agnieszka Stelmaszyk

ul. Rokietnicka 5a, 60-805 Poznań

Phone: 618547258

Fax: 618547252

e-mail: stelmaszyk.agnieszka@gmail.com

Translation: lek. Małgorzata Kamińska

Clinical Diabetology 2017, 6, 4, 142-146

DOI: $10.5603 /$ DK.2017.0024

Received: 18.09.2017

Accepted: 05.10.2017 type 2 diabetes. Cardiovascular (CV) risk in these patients is even 2-4 times higher than in those without carbohydrate metabolism disorders [1]; therefore, CV risk reduction is one of the most important therapeutic goals. The choice of a drug used to normalize blood glucose in type 2 diabetic patient should be made considering the effect of this drug on cardiovascular risk factors and the morbidity and mortality associated with cardiovascular diseases [2].

\section{Dapagliflozin - general characteristics of the drug}

Dapagliflozin is an oral hypoglycaemic agent indicated for the treatment of type 2 diabetes in adult patients. According to the Summary of Product Characteristics (SPC), dapagliflozin may be used alone or in combination, usually at a dose of $10 \mathrm{mg}$ once daily [3].

The mechanism of action of dapagliflozin is selective inhibition of sodium-glucose co-transporter 2 (SGLT2) located in the proximal tubule of the nephron. The role of SGLT2 is to reabsorb about $90 \%$ of glucose and sodium cations from the urine in a 1:1 molar ratio - therefore blocking SGLT2 leads to urinary excretion of these substances. The amount of glucose excreted in the urine in patients receiving dapagliflozin depends on the severity of hyperglycaemia and on glomerular filtration rate (GFR) [4]. Clinical studies have demonstrated the efficacy of dapagliflozin in the reduction of $\mathrm{HbA}_{1 \mathrm{c}}$ and fasting plasma glucose, both when used alone and in combination with other antidiabetic agents. It has also been observed that the efficacy of dapagliflozin in glycaemic control is comparable to that of metformin, sulphonylureas or sitagliptin [4]. 


\section{Dapagliflozin and cardiovascular risk factors}

Available results of basic research and experimental clinical trials of the effect of dapagliflozin on cardiovascular system in type 2 diabetes did not give a clear answer to whether dapagliflozin reduces macrovascular complications (Table 1).

At the same time, further intensive clinical trials are underway to evaluate the effect of dapagliflozin on cardiovascular diseases, and the results of one of these studies - CVD-REAL Nordic - are very promising. The study confirmed that the use of SGLT2 inhibitors significantly reduced cardiovascular mortality. Although the study included patients treated with one of three different SGLT2 inhibitors, most of the observations were from patients treated with dapagliflozin [5].

Dapagliflozin has been used since several years, also in Poland, although its use is significantly limited by the lack of reimbursement. Therefore, knowledge of the currently available data relating to the relationship between dapagliflozin use and vascular complications, especially in the circulatory system, has become indispensable.

\section{Hypertension}

Dapagliflozin decreases blood pressure due to osmotic diuresis. The loss of sodium ions and water resulting from the inhibition of SGLT2 leads to a decrease in both systolic and diastolic blood pressure. This has been demonstrated in clinical studies and results have been confirmed in a meta-analysis of the effect of dapagliflozin on blood pressure. The effect of dapagliflozin on this aspect of cardiovascular risk is observed only 12 weeks after initiation of therapy and the diuretic potency of dapagliflozin is comparable to that of hydrochlorothiazide [6].

\section{Body mass}

Dapagliflozin reduces obesity by decreasing the amount of body fat. In patients treated with dapagliflozin for 24 weeks, body mass was reduced by an average of $2 \mathrm{~kg}$ compared to placebo. Weight loss in the dapagliflozin group was significantly higher and $2 / 3$ of this reduction was due to loss of adipose tissue, whereas in placebo-treated patients only $50 \%$ of weight loss resulted from body fat reduction and $50 \%$ - from decrease in total body water (TBW) [7]. The mechanism by which dapagliflozin causes weight loss is most likely to be associated with urinary glucose excretion, which means elimination of calories from the food [4].

\section{Lipid profile}

Dapagliflozin, like other SGLT2 inhibitors, influences the lipid profile, resulting in decreased serum triglyceride levels and elevated HDL levels. Some studies have shown that SGLT2 inhibitors also increase LDL levels, but the ratio of cardioprotective HDL to atherogenic LDL remains unchanged $[8,9]$. Other reports have shown a reduction in total cholesterol after 90 days of dapagliflozin therapy in patients with type 2 diabetes [10].

\section{Hyperglycaemia and diurnal variations of blood glucose}

Dapagliflozin has been shown to reduce glycaemia and, after 6 months, also $\mathrm{HbA}_{1 \mathrm{c}}$ level by $0.5 \%$. Glucose reduction has been observed both in fasting and postprandial glucose level measurements as well as in glucose tolerance test results. The mechanism of action of dapagliflozin was not associated with insulin secretion and did not increase the incidence of hypoglycaemia [11-14].

Due to the high efficacy in reducing postprandial hyperglycaemia and the lack of effect on the incidence of hypoglycaemia, dapagliflozin may be a drug specifically indicated for use in patients with significant diurnal blood glucose fluctuations, particularly in those with high postprandial glucose excursions. It is known that both postprandial hyperglycaemia and increased blood glucose variability have a negative effect on the development of chronic cardiovascular complications of diabetes $[15,16]$.

Clinical studies showed a beneficial effect of dapagliflozin monotherapy on the reduction of diurnal glycaemic variability, assessed as the mean amplitude of glucose fluctuations, and the reduction of oxidative stress, assessed by plasma 8-prostaglandin F2 $\alpha$ levels [17]. It was also found in 4 week-observation that dapagliflozin in combination with metformin or with insulin reduces the mean amplitude of glucose fluctuations by $10 \mathrm{mg} / \mathrm{dL}$, whereas in patients receiving placebo in combination with metformin or with insulin, the mean fluctuation amplitude increased by $5.3 \mathrm{mg} / \mathrm{dL}$ [18].

\section{Insulin resistance}

Peripheral insulin resistance is a challenge in the treatment of type 2 diabetes. In clinical trials, dapagliflozin has been shown to increase tissue insulin sensitivity as assessed by glucose disappearance rate [19]. In another study, dapagliflozin reduced peripheral insulin resistance in patients with metabolic syndrome, causing remission of metabolic syndrome features in more than half of the patients [10]. On this basis, it can be concluded that the use of dapagliflozin is beneficial in terms of correcting peripheral insulin resistance irrespective of the severity of carbohydrate and lipid disorders. 
Table 1. Review of selected clinical trials of the effect of dapagliflozin on cardiovascular risk (according to https://clinicaltrials.gov, accessed 17.09.2017). Search terms: death, HF — heart failure, MI - myocardial infarction, hospitalization, stroke

\begin{tabular}{|c|c|c|c|c|c|c|}
\hline \multirow[t]{2}{*}{ No. of the study } & \multirow{2}{*}{$\begin{array}{l}\text { End of the } \\
\text { study }\end{array}$} & \multirow{2}{*}{ Duration } & \multirow{2}{*}{$\begin{array}{l}\text { Dapagliflozin dose } \\
\text { (number of patients) }\end{array}$} & \multirow{2}{*}{$\begin{array}{l}\text { Comparator } \\
\text { (number of patients) }\end{array}$} & \multicolumn{2}{|c|}{ Findings } \\
\hline & & & & & Deaths $^{\mathrm{a}}$ & Adverse events ${ }^{b}$ \\
\hline $\begin{array}{l}\text { NCT00263276 } \\
\text { MB102-008 }\end{array}$ & 2007.02 & 12 weeks & $\begin{array}{l}2.5 / 5 / 10 / 20 / 50 \mathrm{mg} \\
\text { (overall 279) }\end{array}$ & $\begin{array}{l}\text { Placebo (54) } \\
\text { Metformin (56) }\end{array}$ & $0: 0$ & $0: 0$ \\
\hline $\begin{array}{l}\text { NCT00357370 } \\
\text { MB102-009 }\end{array}$ & 2008.03 & 12 weeks & 10/20 mg (overall 48) & Placebo (23) & $0: 0$ & $0: 0$ \\
\hline $\begin{array}{l}\text { NCT00528879 } \\
\text { MB102-014 }\end{array}$ & 2008.11 & $\begin{array}{l}24+78 \\
\text { weeks }\end{array}$ & $\begin{array}{l}2.5 / 5 / 10 \mathrm{mg}+\text { metformin } \\
\text { (overall 409) }\end{array}$ & $\begin{array}{l}\text { Placebo + metformin } \\
\text { (137) }\end{array}$ & $2: 0$ & $35: 20$ \\
\hline $\begin{array}{l}\text { NCT00528372 } \\
\text { MB102-013 }\end{array}$ & 2009.02 & $\begin{array}{l}24+78 \\
\text { weeks }\end{array}$ & 2.5/5/10 mg (overall 483) & Placebo $(75)$ & $0: 0$ & $29: 4$ \\
\hline $\begin{array}{l}\text { NCT00673231 } \\
\text { D1690C00006 }\end{array}$ & 2009.05 & $\begin{array}{l}24+80 \\
\text { weeks }\end{array}$ & 2.5/5/10 mg (overall 544) & Placebo (197) & $2: 0$ & $38: 17$ \\
\hline $\begin{array}{l}\text { NCT00643851 } \\
\text { MB102-021 }\end{array}$ & 2009.08 & 24 weeks & $\begin{array}{l}5 \mathrm{mg} \pm \text { metformin XR } \\
\text { (overall 397) }\end{array}$ & $\begin{array}{l}\text { Placebo + metformin XR } \\
\text { (201) }\end{array}$ & $1: 0$ & $4: 1$ \\
\hline $\begin{array}{l}\text { NCT00680745 } \\
\text { D1690C00005 }\end{array}$ & 2009.11 & $\begin{array}{l}24+24 \\
\text { weeks }\end{array}$ & $\begin{array}{l}2.5 / 5 / 10 \mathrm{mg} \\
+ \text { glimepiride (overall } 450 \text { ) }\end{array}$ & $\begin{array}{l}\text { Placebo + glimepiride } \\
\text { (146) }\end{array}$ & $2: 0$ & $21: 10$ \\
\hline $\begin{array}{l}\text { NCT00660907 } \\
\text { D1690C00004 }\end{array}$ & 2009.12 & $\begin{array}{l}52+156 \\
\text { weeks }\end{array}$ & $\begin{array}{l}2.5 / 5 / 10 \mathrm{mg}+\text { metformin } \\
\text { (overall 406) }\end{array}$ & $\begin{array}{l}\text { Glipizide + metformin } \\
(408)\end{array}$ & $0: 2$ & $38: 45$ \\
\hline $\begin{array}{l}\text { NCT00663260 } \\
\text { MB102-029 }\end{array}$ & 2009.12 & 24 weeks & 5/10 mg (overall 168) & Placebo (84) & $4: 3$ & $9: 7$ \\
\hline $\begin{array}{l}\text { NCT00736879 } \\
\text { MB102-032 }\end{array}$ & 2009.12 & 24 weeks & 1/2.5/5 mg (overall 214) & Placebo (68) & $0: 0$ & $0: 0$ \\
\hline $\begin{array}{l}\text { NCT00683878 } \\
\text { MB102-030 }\end{array}$ & 2010.01 & 48 weeks & $\begin{array}{l}5 / 10 \mathrm{mg}+\text { pioglitazone } \\
\text { (overall 281) }\end{array}$ & $\begin{array}{l}\text { Placebo + pioglitazone } \\
\text { (139) }\end{array}$ & $0: 0$ & $2: 0$ \\
\hline $\begin{array}{l}\text { NCT00859898 } \\
\text { MB102-034 }\end{array}$ & 2010.05 & 24 weeks & $\begin{array}{l}10 \mathrm{mg} \pm \text { metformin } \mathrm{XR} \\
\text { (overall } 430 \text { ) }\end{array}$ & $\begin{array}{l}\text { Placebo + metformin XR } \\
\text { (208) }\end{array}$ & $0: N A$ & $2: 1$ \\
\hline $\begin{array}{l}\text { NCT00972244 } \\
\text { D1692C00005 }\end{array}$ & 2010.05 & 12 weeks & 1/2.5/5/10 mg (overall 225) & Placebo (54) & NA:0 & $1: 0$ \\
\hline $\begin{array}{l}\text { NCT00855166 } \\
\text { D1690C00012 }\end{array}$ & 2010.07 & $\begin{array}{l}24+78 \\
\text { weeks }\end{array}$ & $10 \mathrm{mg}+$ metformin (91) & $\begin{array}{l}\text { Placebo + metformin } \\
\text { (91) }\end{array}$ & $0: 0$ & $1: 0$ \\
\hline $\begin{array}{l}\text { NCT00831779 } \\
\text { MB102-045 }\end{array}$ & 2010.08 & 12 weeks & $5 \mathrm{mg}(23)$ & Placebo (21) & $0: 0$ & $0: 0$ \\
\hline $\begin{array}{l}\text { NCT00976495 } \\
\text { MB102-035 }\end{array}$ & 2010.11 & 12 weeks & $10 \mathrm{mg}(24)$ & $\begin{array}{l}\text { Placebo (25) } \\
\text { Hydrochlorothiazide (26) }\end{array}$ & $0: 0$ & $0: 0$ \\
\hline $\begin{array}{l}\text { NCT00984867 } \\
\text { D1690C00010 }\end{array}$ & 2011.03 & $\begin{array}{l}24+24 \\
\text { weeks }\end{array}$ & $\begin{array}{l}10 \text { mg + sitagliptin } \\
\pm \text { metformin (225) }\end{array}$ & $\begin{array}{l}\text { Placebo + sitagliptin } \\
\pm \text { metformin (226) }\end{array}$ & $0: 0$ & $3: 1$ \\
\hline $\begin{array}{l}\text { NCT01031680 } \\
\text { D1690C00018 }\end{array}$ & 2011.05 & $\begin{array}{l}24+80 \\
\text { weeks }\end{array}$ & $10 \mathrm{mg}(460)$ & Placebo (462) & $3: 3$ & $7: 10$ \\
\hline $\begin{array}{l}\text { NCT01042977 } \\
\text { D1690C00019 }\end{array}$ & 2011.05 & $\begin{array}{l}24+80 \\
\text { weeks }\end{array}$ & $10 \mathrm{mg}(482)$ & Placebo (483) & NA:NA & $17: 19$ \\
\hline $\begin{array}{l}\text { NCT01095653 } \\
\text { MB102-054 }\end{array}$ & 2012.03 & 24 weeks & $5 / 10 \mathrm{mg}$ (overall 261) & Placebo (132) & $0: 0$ & $0: 1$ \\
\hline $\begin{array}{l}\text { NCT01294423 } \\
\text { D1692C00006 }\end{array}$ & 2012.03 & 24 weeks & 5/10 mg (overall 174) & Placebo (87) & $0: 0$ & $3: 5$ \\
\hline $\begin{array}{l}\text { NCT02397421 } \\
2014-002742-42\end{array}$ & 2017.08 & 1 year & $\begin{array}{l}10 \mathrm{mg} \text { (overall, dapa- } \\
\text { gliflozin and placebo, 56) }\end{array}$ & Placebo & & \\
\hline $\begin{array}{l}\text { NCT01730534 } \\
\text { D1693C00001 }\end{array}$ & 2019.04 & 6 years & $\begin{array}{l}10 \mathrm{mg} \text { (overall, dapa- } \\
\text { gliflozin and placebo, } \\
17276 \text { ) }\end{array}$ & Placebo & & \\
\hline $\begin{array}{l}\text { NCT03036124 } \\
\text { D1699C00001 } \\
2016-003897-41\end{array}$ & 2019.12 & 3 years & $\begin{array}{l}\text { 5/10 mg (overall about } \\
2250 \text { ) }\end{array}$ & Placebo (about 2250) & & \\
\hline $\begin{array}{l}\text { NCT03036150 } \\
\text { D169AC00001 } \\
\text { 2016-003896-24 }\end{array}$ & 2020.11 & 4 years & $\begin{array}{l}5 / 10 \mathrm{mg} \\
\text { (overall about 2000) }\end{array}$ & Placebo (about 2000) & & \\
\hline $\begin{array}{l}\text { TOTAL (studies wl } \\
\text { lished until } 17.09\end{array}$ & $\begin{array}{l}\text { hich results } \\
\text {.2017) }\end{array}$ & were pub- & 6868 & 3403 & $\begin{array}{c}16: 8 \\
0.23 \%: 0.24 \%\end{array}$ & $\begin{array}{c}245: 161 \\
3.57 \%: 4.73 \%\end{array}$ \\
\hline
\end{tabular}

a Cardiovascular mortality among dapagliflozin vs. comparator-treated patients; ${ }^{b}$ number of adverse cardiovascular events among dapagliflozin vs. comparator-treated patients; NA - not available 
Hyperuricaemia and albuminuria

Albuminuria and elevated serum uric acid levels are favorably modified by dapagliflozin [20, 21].

The adjusted mean change from baseline in serum uric acid after 12 weeks of treatment with $10 \mathrm{mg}$ of dapagliflozin was $-0.3 \mathrm{mg} / \mathrm{dL}$ versus $+0.1 \mathrm{mg} / \mathrm{dL}$ in the placebo arm of the study [21].

The effect on urinary albumin excretion is independent from changes in $\mathrm{HbA}_{1 \mathrm{c}}$ levels, blood pressure, body mass, and estimated glomerular filtration rate [20]. Beneficial renoprotective effect of dapagliflozin is manifested by the reduction of albuminuria by $30 \%$ compared to placebo and by decreased inflammation in the kidneys [20].

\section{Dapagliflozin therapy and cardiovascular complications}

Preliminary reports on the safety of dapagliflozin in terms of cardiovascular risk are included in the 2012 report of the European Medicines Agency [22]. Metaanalysis included 14 Phase $2 \mathrm{~b}$ and Phase 3 clinical trials completed before July 15,2011 . Also preliminary data from five further clinical trials which were to be completed later have been included there. Although the studies included in the meta-analysis were not designed to assess the effect of dapagliflozin on cardiovascular system, cardiovascular death, myocardial infarction, or major adverse cardiovascular events (MACE) were registered, as well as hospitalizations due to unstable ischaemic heart disease (IHD). In this meta-analysis of studies lasting from 12 weeks to 208 weeks, there were 145 cases of MACE or hospitalization due to unstable IHD; however, hazard ratio (HR) for these complications was 0.819 (95\% Cl 0.583-1.152) for the dapagliflozintreated group versus the placebo-treated group. Thus, dapagliflozin has been shown to effectively reduce cardiovascular risk compared to placebo [22].

The beneficial effect of dapagliflozin on cardiovascular risk reduction has also been demonstrated in another meta-analysis by Sonesson et al. [23]. The incidence of MACE and unstable IHD in the dapagliflozintreated group in relations to control group matched for age, BMI, duration of diabetes, smoking, eGFR, LDL cholesterol and blood pressure were analysed. After about four years of treatment, dapagliflozin has been shown to reduce the risk of MACE and/or unstable angina in all groups of patients, even in those with a history of cardiovascular events and hypertension [23].

The most promising clinical trial of the effect of dapagliflozin on cardiovascular risk is the ongoing phase 3 study, DECLARE-TIMI58 [24]. The main objective of this study is to analyse the incidence of MACE, the need for hospitalization for unstable IHD, and all-cause mortality.
Approximately 26,000 patients with type 2 diabetes over 40 years of age who are at high risk of cardiovascular complications are enrolled. The study is underway [24].

\section{Conclusions}

Short-term clinical trials, including relatively small groups of patients, suggest positive influence of dapagliflozin on the cardiovascular system. Currently ongoing long-term trials are likely to confirm these data, but so far we can assume that dapagliflozin not only acts as an efficient antihyperglycaemic drug, but also protects the circulatory system in patients with type 2 diabetes mellitus.

\section{REFERENCES}

1. Stamler J, Vaccaro O, Neaton JD, et al. Diabetes, other risk factors, and 12-yr cardiovascular mortality for men screened in the Multiple Risk Factor Intervention Trial. Diabetes Care. 1993; 16(2): 434-444, doi: 10.2337/diacare.16.2.434, indexed in Pubmed: 8432214.

2. Ferrannini $E$, DeFronzo RA. Impact of glucose-lowering drugs on cardiovascular disease in type 2 diabetes. Eur Heart J. 2015; 36(34): 2288-2296, doi: 10.1093/eurheartj/ehv239, indexed in Pubmed: 26063450.

3. Charakterystyka produktu leczniczego Forxiga $5 \mathrm{mg}, 10 \mathrm{mg} 2017$.

4. Scheen AJ. Pharmacodynamics, efficacy and safety of sodium-glucose co-transporter type 2 (SGLT2) inhibitors for the treatment of type 2 diabetes mellitus. Drugs. 2015; 75(1): 33-59, doi: 10.1007/s40265-014-0337-y, indexed in Pubmed: 25488697.

5. Birkeland KI, Jørgensen ME, Carstensen B, et al. Cardiovascular mortality and morbidity in patients with type 2 diabetes following initiation of sodium-glucose co-transporter-2 inhibitors versus other glucose-lowering drugs (CVD-REAL Nordic): a multinational observational analysis. Lancet Diabetes Endocrinol. 2017; 2(17): 1-9.

6. Liakos A, Karagiannis T, Bekiari E, et al. Update on long-term efficacy and safety of dapagliflozin in patients with type 2 diabetes mellitus. Ther Adv Endocrinol Metab. 2015; 6(2): 61-67, doi: 10.1177/2042018814560735, indexed in Pubmed: 25941564.

7. Bolinder J, Ljunggren Ö, Kullberg J, et al. Effects of dapagliflozin on body weight, total fat mass, and regional adipose tissue distribution in patients with type 2 diabetes mellitus with inadequate glycemic control on metformin. J Clin Endocrinol Metab. 2012; 97(3): 1020-1031, doi: 10.1210/jc.2011-2260, indexed in Pubmed: 22238392.

8. Halimi S, Vergès B. Adverse effects and safety of SGLT-2 inhibitors. Diabetes Metab. 2014; 40(6 Suppl 1): S28-S34, doi: 10.1016/ /S1262-3636(14)72693-X, indexed in Pubmed: 25554069.

9. Singh JSS, Fathi A, Vickneson K, et al. Research into the effect Of SGLT2 inhibition on left ventricular remodelling in patients with heart failure and diabetes mellitus (REFORM) trial rationale and design. Cardiovasc Diabetol. 2016; 15: 97, doi: 10.1186/s12933016-0419-0, indexed in Pubmed: 27422625.

10. González-Ortiz M, Méndez-Del Vi, Martínez-Abundis E, et al. Effect of dapagliflozin administration on metabolic syndrome, insulin sensitivity, and insulin secretion. Minerva Endocrinol. 2016: 2016.

11. Bailey CJ, Gross JL, Hennicken D, et al. Dapagliflozin add-on to metformin in type 2 diabetes inadequately controlled with metformin: a randomized, double-blind, placebo-controlled 102-week trial. BMC Med. 2013; 11: 43, doi: 10.1186/1741-701511-43, indexed in Pubmed: 23425012.

12. Cefalu WT, Leiter LA, de Bruin TWA, et al. Dapagliflozin's Effects on Glycemia and Cardiovascular Risk Factors in High-Risk Patients 
With Type 2 Diabetes: A 24-Week, Multicenter, Randomized, Double-Blind, Placebo-Controlled Study With a 28-Week Extension. Diabetes Care. 2015; 38(7): 1218-1227, doi: 10.2337/ /dc14-0315, indexed in Pubmed: 25852208.

13. Strojek K, Yoon $\mathrm{KH}$, Hruba V, et al. Effect of dapagliflozin in patients with type 2 diabetes who have inadequate glycaemic control with glimepiride: a randomized, 24-week, double-blind, placebo-controlled trial. Diabetes Obes Metab. 2011; 13(10): 928-938, doi: 10.1111/j.1463-1326.2011.01434.x, indexed in Pubmed: 21672123.

14. Bolinder J, Ljunggren Ö, Johansson L, et al. Dapagliflozin maintains glycaemic control while reducing weight and body fat mass over 2 years in patients with type 2 diabetes mellitus inadequately controlled on metformin. Diabetes Obes Metab. 2014; 16(2): 159-169, doi: 10.1111/dom.12189, indexed in Pubmed: 23906445.

15. Nalysnyk L, Hernandez-Medina M, Krishnarajah G. Glycaemic variability and complications in patients with diabetes mellitus: evidence from a systematic review of the literature. Diabetes Obes Metab. 2010; 12(4): 288-298, doi: 10.1111/j.1463-1326.2009.01160.x, indexed in Pubmed: 20380649.

16. Suh S, Kim JH. Glycemic Variability: How Do We Measure It and Why Is It Important? Diabetes Metab J. 2015; 39(4): 273-282, doi: 10.4093/dmj.2015.39.4.273, indexed in Pubmed: 26301188.

17. Li FF, Gao Gu, Li Q, et al. Influence of Dapagliflozin on Glycemic Variations in Patients with Newly Diagnosed Type 2 Diabetes Mellitus. J Diabetes Res. 2016; 2016: 5347262, doi: 10.1155/2016/5347262, indexed in Pubmed: 27738639.
18. ClinicalTrials.gov. Effect of Dapagliflozin on 24-hour Blood Glucose in T2DM Patients Inadequately Controlled With Either Metformin Or Insulin - Study Results. https://clinicaltrials.gov/ /ct2/show/results/NCT02429258 (2017).

19. Mudaliar S, Henry RR, Boden G, et al. Changes in insulin sensitivity and insulin secretion with the sodium glucose cotransporter 2 inhibitor dapagliflozin. Diabetes Technol Ther. 2014; 16(3): 137-144, doi: 10.1089/dia.2013.0167, indexed in Pubmed: 24237386.

20. Heerspink HJL, Johnsson E, Gause-Nilsson I, et al. Dapagliflozin reduces albuminuria in patients with diabetes and hypertension receiving renin-angiotensin blockers. Diabetes Obes Metab. 2016; 18(6): 590-597, doi: 10.1111/dom.12654, indexed in Pubmed: 26936519.

21. Weber MA, Mansfield TA, Alessi F, et al. Effects of dapagliflozin on blood pressure in hypertensive diabetic patients on renin-angiotensin system blockade, Blood Pressure, 2016; 25(2): 93-103, doi: 10.3109/08037051.2015.1116258, indexed in Pubmed: 26623980.

22. European Medicines Agency. Assessment report - Forxiga. 2012.

23. Sonesson C, Johansson PA, Johnsson E, et al. Cardiovascular effects of dapagliflozin in patients with type 2 diabetes and different risk categories: a meta-analysis. Cardiovasc Diabetol. 2016; 15: 37 , doi: 10.1186/s12933-016-0356-y, indexed in Pubmed: 26895767.

24. ClinicalTrials.gov. Multicenter Trial to Evaluate the Effect of Dapagliflozin on the Incidence of Cardiovascular Events - Full Text View - ClinicalTrials.gov [Internet]. 2017. p. 6-8. https://www. clinicaltrials.gov/ct2/show/NCT01730534 (2017) 